\title{
Role of Fashion Involvement and Hedonistic Consumption towards Fashion Apparel Industry
}

\author{
Shaifali Chauhan \\ Research Scholar, SOS Management Jiwaji University, Gwalior, India \\ Richa Banerjee, Ph.D. \\ Assistant Professor, Prestige Institute of Management, Gwalior, India \\ Nischal Risal \\ Lecturer, Nepal Commerce Campus, Tribhuvan University, Nepal
}

\begin{abstract}
Fashion clothes industry is dependent on endless ideas and new opportunities. The apparel industry replicates people's lifestyles and represents their social and economic status. The study aims on analyzing the impact of fashion involvement and hedonistic consumption tendency on purchase intention towards fashion apparel industry. The sample contained the representation of population from different cities between the age group 18 to 40 . The purposive sampling technique, non-probability sampling techniques and 200 respondents had been selected to collect the data. The result specified that the data was highly reliable with the different values as reported by Cronbach's Alpha test. Factor analysis, ANOVA, and regression analysis had been done to analyze the data. The regression analysis concluded and proved that there was a positive significant impact of fashion involvement and hedonistic consumption tendency on purchase intention.
\end{abstract}

Keywords: Fashion Involvement, Hedonistic Consumption Tendency, Purchase Intention, Consumer Behavior, Fashion Industry

\section{Introduction}

In recent years fashion industry is gaining importance in the business world. India is one of the dynamic countries in fashion Industry. For the last few decades, the fashion industry in India is experiencing growth due to increasing awareness for fashion apparels among Indians. We can easily evaluate that Indian market is changing with the recent swings in apparels Industry. India is also known for its fashion values; ethnic values, and traditional apparels have been distinctiveness for Indian market. In Indian market, modern consumption behavior have changed and progressed, where consumers are more attentive towards fashion fiesta and updates for those are easily accessible to consumers for all segment through different media channels. The present consumption behavior has changed the customers enthusiasm behind their consumption, some customer uses fashion as a way of presenting themselves towards the society. Fashion is lively event always changes according to time; not restriction to a garment, cosmetics, or jewelers.

\section{Involvement}

Involvement originates from societal psychology along with explicitly from the influential communiqué, wherever the community judgment-participation has been worn to elucidate to the approach 
and mind-set changes (Sherif and Sargent, 1947; Sherif, Sherif, and Nebergall (1965). Involvement is discussed in three forms in detail.

\section{Enduring Involvement}

The social-psychological phenomenon has been stated on the viewpoint of ego involvement and considers the superficial individual consequence of an entity to an individual. This approach treats involvement as the concentration of an approach that is reliant on the consequence of that outlook (Sherif, Sherif, and Nebergall, 1965). As a result, involvement is viewed as belongings of a mind-set, which is lasting or constant over time.

\section{Situational Involvement}

The essential belonging of involvement is that it represents an intellectual state in the outward appearance of an impermanent apprehension with a motivation object. This form of involvement is focused as a theme of concentration, referring to the grade of, the amount of, or the intensity of awareness, enthusiasm, or provocation. Disparate enduring involvement, situational involvement represents a 'mind set'; a provisional apprehension with a motivation objective with the intention of its usual aroused by a meticulous cause such as alleged risk (Dholakia, 1997).

\section{Response Involvement}

This type of involvement refers to a behavioral direction that involves in sequence to acquirement and pronouncement processes. In this framework, of involvement is seen as performance to a certain extent than as an arbitrator behavior (Dholakia, 1997).

\section{Utilitarian Value}

Barry, Darden, and Giffin (1994) asserted that all shopping experiences engaged the inspiration of thoughts and/or wits and that they consequently might be viewed as a procedure that offer the individual with cognitive (utilitarian) and emotional (hedonic) reimbursement. More purposely, substantial attributes of goods and services endow an input to cognitive procedure and intimately associated to assessment of utilitarian value. Thus, a consumer receives utilitarian shopping value as soon as he or she obtains the desirable product, in addition to this worth increases as the consumer obtains the product supplementary fluently.

\section{Hedonic Value}

Compared to utilitarian value, hedonic shopping value is supplementary prejudiced and individualistic. Its value seems throughout fun and enjoyment as conflicting to goal accomplishment (Hirschman and Holbrook, 1982). Also, hedonic shopping value reflects the happiness and arousing attraction of shopping (Bellenger, Steinberg, and Stanton, 1976). Recently, as the requirements of consumers have developed into additional miscellaneous, hedonic shopping value has been studied vastly. In the past, however, there was a considerable lack of studies examining hedonic shopping value compared to utilitarian shopping value (Sherry, 1990).

\section{Literature Review}

Babin and Babin (2001) concluded that the compulsiveness was correlated significantly to hedonic value. It was unrelated among utilitarian value, which reflected functional product attainment. The result specified that consumers often apply shopping as a tool in managing their emotions. In the container of compulsive consumption, the therapy could rapidly turn into a disparaging behavior. Kang and Park-Poaps (2010) found the relationships among fashion innovativeness/outlook leadership as well as utilitarian/ 
hedonic shopping motivations. The study concluded that fashion innovativeness was significantly correlated with hedonic shopping motivations and ideal shopping motivations. Zhang and Kim (2013) studied on three major cities in China i.e., Beijing, Shanghai, and Guangzhou to examine the influencing factors that affect Chinese consumer's perspective towards purchase intention of luxury fashion goods. The results indicated that brand consciousness played a vital role in forecasting Chinese consumers' mind-set towards purchasing luxury fashion goods. Chinese consumers always seemed to be more inclined towards luxury brands which easily reflected their social status. The brand consciousness of Chinese consumer and their attitude towards buying luxury goods played a very important role. Haq, Khan, and Ghouri (2014) confirmed the mediating relationship between impulse buying, hedonic consumption and fashion involvement. The study concluded fashion involvement impact on impulse buying through hedonic consumption. Dhurup (2014) concluded that there was a positive relationship between hedonism, fashion involvement, and emotional gratification. Rimpy (2014) concluded that high quality, best design, and value for money were the top three reasons in purchasing of luxury products. Osorno (2014) concluded the significant effect of fashion blogs, online shopping (stimuli), ethical fashion, hedonic consumption, involvement (organism) in the fast fashion industry, fashion consumers, and on the purchase intention. Khuong and Tran (2015) found that novelty-fashion consciousness, consumer self-spending control, and hedonic purchase had effect in increasing impulse buying. Ali, Amin, and Jayashree (2016) concluded the solidity, keenness, authenticity, superiority, and repulsiveness were the insights as the implication of outcome stated. Website personality was optimistically motivating, hedonic web browsing, utilitarian web browsing, and online impulse buying; both utilitarian web browsing and hedonic web browsing optimistically motivating online impulse buying therefore there was a significant relationship among the variable. Lam, Lee, Ong, and Tan, (2017) identified the factors which influenced on the intention of young generation towards purchasing of fashion apparel of age group 20- 30 years. The result indicated relationship between novelty-fashion consciousness purchase intention and the influence of fashion involvement towards purchase intention had proven to be sufficient and prominent. The study further concluded impact on influencing decision of young generation on purchasing fashion apparel. Bhardwaj, Marcos, and Manchiraju (2017) concluded that impulse buying tendency had undesirable influenced while hedonism had optimistic influence toward attitudes toward sustainable consumption of fast fashion. Hence, the study aimed to analyze the underlying factors of fashion involvement, hedonistic consumption tendency, and purchase intention. The study had been extended to analyze the impact of fashion involvement and hedonistic consumption tendency on purchase intention towards fashion apparel industry. The conceptual model of the study had been presented in Figure 1.

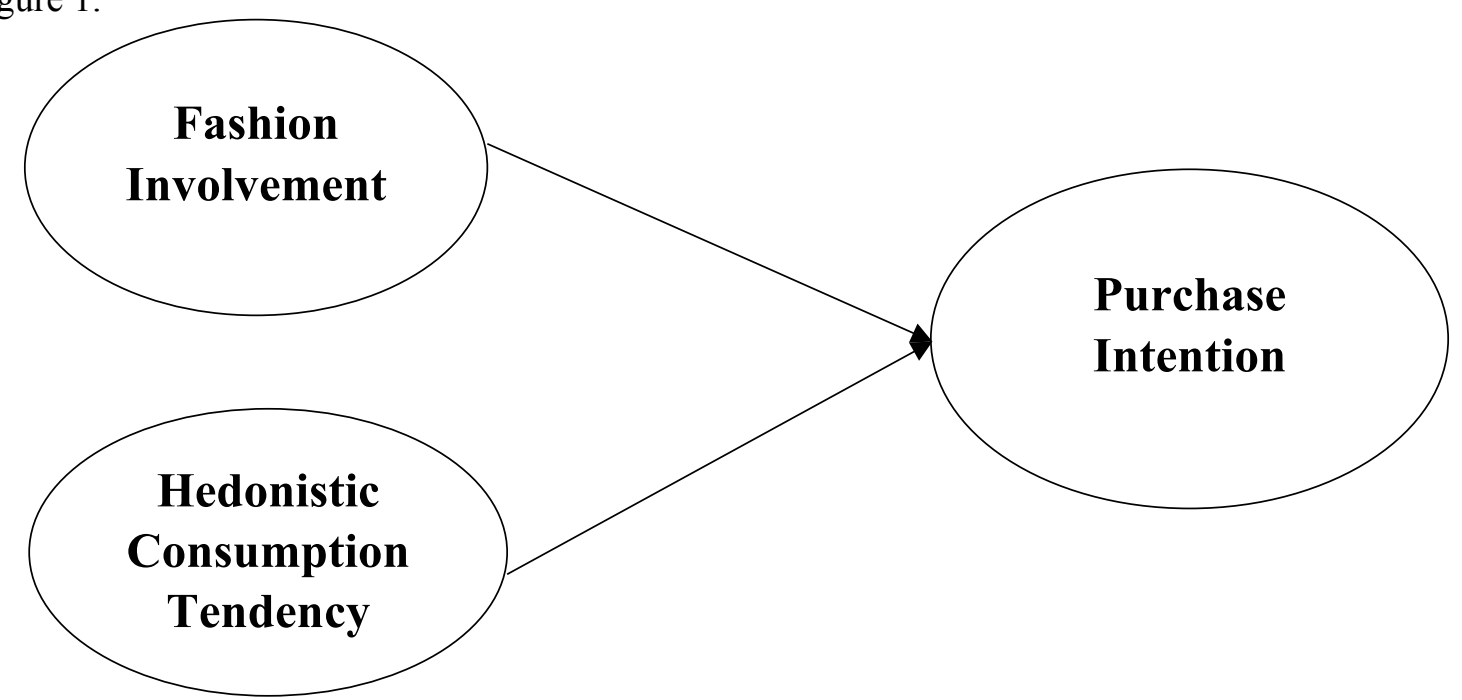

Figure 1: Conceptual Model 


\section{Research Methods}

The research design is based on the causal research concept that explains the cause and effect relationship among variables. The fashion apparel users in India were the population of the study. The sample represents the population. Hence, the purposive sampling method had been used which come under non probability sampling techniques and 200 responders were selected to collect data. Primary data had been collected using self-structured questionnaires with the scale of Likert type which was 1 to 5 where 1 stands for strongly disagreement and 5 for strongly agreement. The online data collection procedure had been used which consisted Google forms in social media network. The collected data was tested with the help of reliability analysis to check the reliability of questionnaire. The factor and regression analysis were conducted to evaluate the relationship between purchase intention and fashion Involvement and hedonistic consumption tendency.

\section{Hypothesis}

$H_{I}$ : Fashion involvement has no impact on Purchase Intention towards fashion apparel industry.

$\mathrm{H}_{2}$ : Hedonistic consumption tendencies have no impact on Purchase Intention towards fashion apparel industry.

\section{Results and Discussion}

\section{Reliability Analysis}

Table1

Reliability Statistics

\begin{tabular}{lccc}
\hline Variable Name & Cronbach's Alpha & $\begin{array}{c}\text { Cronbach's Alpha Based on } \\
\text { Standardized Items }\end{array}$ & N of Items \\
\hline Fashion Involvement & .841 & .841 & 8 \\
Hedonistic Consumption tendency & .886 & .887 & 7 \\
Purchase intention & .893 & .893 & 8 \\
\hline
\end{tabular}

Table 1 had shown the reliability values of the questionnaires. Reliability of individual variable questionnaire was checked. The reliability test revealed Cronbach's Alpha value which was more than the standardized value (.8). It was considered the adequate reliability of all the measures. So, the statement in the questionnaire was treated as reliable statements.

\section{Factor Analysis}

Factor analysis had been used to measure the impact of a few unobserved variables (factors) on observed variables. It had been the way of reducing data. The study had used principal factor analysis or common factor analysis to identify minimum number of factors having correlation between variables. The study had applied principal component factor analysis with varimax rotation to identify the factors underlying the three variables.

\section{Fashion Involvement}

The raw scores of 8 items were subjected to factor analysis to find out the factors that contribute towards fashion involvement. After factor analysis two factors were identified. 
Table 2

KMO and Bartlett's Test (Fashion Involvement)

\begin{tabular}{lll}
\hline Kaiser-Meyer-Olkin Measure of Sampling Adequacy. & .821 \\
\hline Bartlett's Test of Sphericity & Approx. Chi-Square & 592.888 \\
& Df & 28 \\
& Sig. & .000 \\
\hline
\end{tabular}

The KMO value of the sample more than 0.5 had been considered as good and Table 2 had shown the value 0.821 which indicated that the sample taken for factor analysis was acceptable. The chi square value 592.888 was found significant at 5 percentages level of significance.

Table 3

Factor Analysis (Fashion Involvement)

\begin{tabular}{|c|c|c|c|c|}
\hline \multirow{2}{*}{ Factor Name } & \multicolumn{2}{|c|}{ Eigen value } & \multirow{2}{*}{ Variable Coverage } & \multirow{2}{*}{ Loading } \\
\hline & Total & $\%$ Variance & & \\
\hline \multirow{8}{*}{$\begin{array}{l}\text { Fashion clothing } \\
\text { involvement }\end{array}$} & 3.800 & 47.498 & I am concerned in the way I present myself to & .874 \\
\hline & & & look good. & \\
\hline & & & I am aware of fashion trends and want to be one & .781 \\
\hline & & & of the first to try them & \\
\hline & & & Clothes are one of the most important ways I & .773 \\
\hline & & & have of individuality & \\
\hline & & & I am confident in my ability to recognize fashion & .683 \\
\hline & & & trends. & \\
\hline \multirow{5}{*}{$\begin{array}{l}\text { Consumer confidence } \\
\text { in fashion decisions }\end{array}$} & 1.325 & 16.558 & It gives me pleasure to buy high priced clothes & .824 \\
\hline & & & I think I am impatient, if I want to possess & .740 \\
\hline & & & $\begin{array}{l}\text { something, I buy it readily and quickly } \\
\text { For my fashion needs, I am increasingly }\end{array}$ & .729 \\
\hline & & & shopping at boutiques or fashion specialty stores & \\
\hline & & & $\begin{array}{l}\text { rather than department stores } \\
\text { I am the first to try new fashion; therefore, many } \\
\text { people regard me as being a fashion leader }\end{array}$ & .712 \\
\hline
\end{tabular}

\section{Hedonistic Consumption Tendency}

The KMO value of the sample more than 0.5 had been considered as good. Table 3 shown the value 0.887 which indicated that the sample taken for factor analysis was acceptable. Table 4 had shown that Chi square value 651.346 was found significant at 5 percentages level of significance. The rotated factor matrix could not be generated because all items were converged under one factor.

Table 4

KMO and Bartlett's Test (Hedonistic Consumption Tendency)

\begin{tabular}{lll}
\hline \multicolumn{2}{l}{ Kaiser-Meyer-Olkin Measure of Sampling Adequacy. } & .887 \\
\hline Bartlett's Test of Sphericity & Approx. Chi-Square & 651.346 \\
& Df & 21 \\
& Sig. & .000 \\
\hline
\end{tabular}




\section{Purchase Intention}

The raw scores of 8 items were subjected to factor analysis to find out the factors that contribute towards purchase intention. After factor analysis, 2 factors were identified.

Table 5

KMO and Bartlett's Test (Purchase Intention)

\begin{tabular}{lll}
\hline Kaiser-Meyer-Olkin Measure of Sampling Adequacy. & .870 \\
\hline Bartlett's Test of Sphericity & Approx. Chi-Square & 928.104 \\
& Df & 28 \\
& Sig. & .000 \\
\hline
\end{tabular}

The KMO value of the sample more than 0.5 had been considered as good and Table 5 had shown the value 0.870 which indicated that the sample taken for factor analysis was acceptable. The Chi square value 928.104 was found significant at 5 percentages level of significance.

Table 6

Factor Analysis (Purchase Intention)

\begin{tabular}{|c|c|c|c|c|}
\hline \multirow{2}{*}{$\begin{array}{l}\text { Factor } \\
\text { Name }\end{array}$} & \multicolumn{2}{|c|}{ Eigen value } & \multirow{2}{*}{ Variable coverage } & \multirow{2}{*}{ Loading } \\
\hline & Total & $\%$ variance & & \\
\hline \multirow{9}{*}{$\begin{array}{l}\text { Purchase } \\
\text { behavior }\end{array}$} & 4.680 & 58.497 & I want to get notice by people for buying expensive & .895 \\
\hline & & & clothes & \\
\hline & & & I tend to purchase expensive clothes to enhance my & .857 \\
\hline & & & social status. & \\
\hline & & & I tend to purchase luxurious fashion apparel to flaunt & .744 \\
\hline & & & myself & \\
\hline & & & Shopping luxurious apparel gives me lot of enjoyment. & .704 \\
\hline & & & I tend to purchase luxurious fashion apparel to & .689 \\
\hline & & & differentiate myself from others. & \\
\hline \multirow{5}{*}{$\begin{array}{l}\text { Purchase } \\
\text { satisfaction }\end{array}$} & 1.078 & 13.481 & I tend to purchase on fashion apparel that makes me feel & .857 \\
\hline & & & $\begin{array}{l}\text { good in which I can represent my style of personality. } \\
\text { I am conscious about fashion and novelty seeking so I }\end{array}$ & .668 \\
\hline & & & $\begin{array}{l}\text { would purchase any latest fashion apparel. } \\
\text { Ifind that luxurious brand plavs an important role in }\end{array}$ & 668 \\
\hline & & & influencing my purchase intention towards fashion & \\
\hline & & & apparel. & \\
\hline
\end{tabular}

\section{Description of Factors}

The raw scores of 23 items were subjected to factor analysis to find out the factors that contribute towards Fashion Involvement, Hedonistic Consumption Tendency and Purchase Intention. After factor analysis, 4 factors were identified.

\section{Fashion Clothing Involvement}

This factor had emerged as the most important determinant of fashion involvement with total variance of 47.498 percentages. It had included the statements related to concerned in the way the respondents presented themselves to look good (.874), awared of fashion trends and wanted to be one of the first to try them (.781), clothes were one of the most important ways the respondents had of individuality (.773), 
confident in the respondents ability to recognize fashion trends (.683).

\section{Consumer Confidence in Fashion Decisions}

This factor had emerged as the most important determinant of fashion involvement with total variance of 16.558 percentages. It had included the statements related to pleasure to buy high priced clothes (.824), impatient, want to possess something, the respondents bought it readily and quickly (.740), fashion needs, increasingly shopping at boutiques or fashion specialty stores rather than department stores (.729), first to try new fashion; therefore, many people regard the respondents as being a fashion leader (.712).

\section{Purchase Behavior}

This factor had emerged as the most important determinant of purchase intention with total variance of 58.497 percentages. It had included the statements the respondents wanted to get notice by people for buying expensive clothes (.895), the respondents tend to purchase expensive clothes to enhance their social status (.857), the respondents tend to purchase luxurious fashion apparel to flaunt themselves (.744), shopping luxurious apparel gives the respondents lot of enjoyment (.704), the respondents tend to purchase luxurious fashion apparel to differentiate themselves from others (.689).

\section{Purchase Satisfaction}

This factor had emerged as the most important determinant of purchase intention with total variance of 13.481 percentages. It had included the statements the respondents tend to purchase on fashion apparel that made them feel good in which they could represent their style of personality (.857), the respondents were conscious about fashion and novelty seeking so, they would purchase any latest fashion apparel (.668), the respondents found that luxurious brand played an important role in influencing their purchase intention towards fashion apparel (.668).

\section{Analysis of Impact of Fashion Involvement, Hedonistic Consumption Tendency on Purchase Intention}

The multiple regression analysis had been conducted to identify the relationship among fashion involvement, hedonistic consumption tendency and purchase intention. Where fashion involvement, hedonistic consumption tendency were independent variables and purchase intention was taken as dependent variable.

Table 7

Coefficient of Determination

\begin{tabular}{|c|c|c|c|c|}
\hline \multicolumn{5}{|c|}{ Model Summary } \\
\hline Model & $\mathrm{R}$ & R Square & Adjusted R Square & Std. Error of the Estimate \\
\hline 1 & .815 & .665 & .661 & 4.01486 \\
\hline
\end{tabular}

Table 7 had shown the model summary of regression analysis of the three variables that were fashion involvement, hedonistic consumption tendency on purchase intention. The $\mathrm{R}$ value explained the correlation coefficient among three variables. The value of $\mathrm{R}$ square indicated the predicting the explained variance in dependent variable (purchase intention) with the help of fashion involvement and hedonistic consumption tendency. Table 7 had shown that 66.10 percentages variance in purchase intention could be explained with the help of fashion involvement and hedonistic Consumption tendency. 
Issue 1 May/June 2020

Table 8

Analysis of Variance (ANOVA) (Test of Model Fit)

\begin{tabular}{llccccc}
\hline Model & & Sum of Squares & Df & Mean Square & F & Sig. \\
\hline \multirow{2}{*}{1} & Regression & 6293.722 & 2 & 3146.861 & 195.226 & .000 \\
& Residual & 3175.458 & 197 & 16.119 & & \\
& Total & 9469.180 & 199 & & & \\
\hline
\end{tabular}

Table 8 had shown that the value of $\mathrm{F}$ was found 195.226 and significant at 5 percentages level of significance, signified that the model of the study was a good fit.

Table 9

Analysis of Relationship between the Variables

\begin{tabular}{|c|c|c|c|c|c|c|}
\hline \multirow{2}{*}{ Model } & & \multicolumn{2}{|c|}{ Unstandardized Coefficients } & \multirow{2}{*}{$\begin{array}{l}\text { Standardized Coefficients } \\
\text { Beta }\end{array}$} & \multirow{2}{*}{$\mathrm{T}$} & \multirow{2}{*}{ Sig. } \\
\hline & & B & Std. Error & & & \\
\hline \multirow{3}{*}{1} & (Constant) & 3.047 & 1.375 & & 2.215 & .028 \\
\hline & Fashion & .277 & .077 & .234 & 3.576 & .000 \\
\hline & Hedonic & .699 & .074 & .620 & 9.464 & .000 \\
\hline
\end{tabular}

Table 9 explained the overall impact of fashion involvement and hedonistic consumption tendency on purchase intention. The beta coefficient of fashion involvement was found to be .234 , beta coefficient of hedonistic consumption tendency was found to be .620 and t value of fashion involvement is 3.576 at 5 percentages level of significance. The t-value of hedonistic consumption tendency was found to be 9.464 at 5 percentages level of significance. Hence, the null hypothesis had been rejected and the study concluded that fashion involvement and hedonistic consumption tendency had significant impact on the purchase intention.

\section{Conclusions}

In current scenario, hedonism is the reason of maximum purchases made by consumers for fashion (Dhurup, 2014). Consumer remains the heart of a business and plays a significant role for researchers and marketers to have better understanding about the intention of customers to buy or resist the attraction to make a purchase and what are the confounding factors that affect the purchase intention of consumers who are vastly involved in fashion and hedonistic consumption tendency (Kang and Park-Poaps, 2010). This research examined about the impact of fashion involvement, hedonistic consumption tendency on purchase intention by setting the sample of customer between the age group of 18 to 40, after collecting the data reliability test has been applied and the results are highly reliable. This study also attempted to identify some of the factors that help in explaining the fashion involvement, hedonistic consumption tendency and purchase intention. Therefore, the study found that fashion involvement have 2 factors and purchase intention have 2 factors after which regression test has been applied to find out the effect of fashion involvement, hedonistic consumption tendency on purchase intention. Hence, the result concludes that fashion involvement and hedonistic consumption tendency have significant impact on the purchase intention. Thus, the study supports the notion of consumer behavior theory.

\section{Implications}

The study concludes on the usefulness of the hedonic perspective in supplementing and extending the market research on consumer behaviour. The further study with the breakdown of the hedonic consumption tendency into mental constructs, product classes, product usage and individual differences may produce more 
concrete findings. The fashion involvement focused product would create positive interest to the customers. The clothing industry can focus on the worth and application of clothing in the lives of consumers and show their consumption behaviour. The study results help the concerned associates for market segmentation, customer identification and to develop sustainable fashion market.

\section{References}

Babin, B., Babin, L. (2001). Seeking something different? A model of schema typicality, consumer affect, purchase intentions and perceived shopping value. Journal of Business Research, 54 (2), 89-96.

Barry, B.J., Darden,W.R., Giffin, M. (1994). Work or fun measuring hedonic and utilitarian shopping value. Journal of Consumer Research, 20 (4), 644-656, https://doi.org/10.1086/209376

Bellenger, D.N., Steinberg, E., and Stanton, W.W. (1976). The congruence of store image and self image: As it relates to store loyalty. Journal of Retailing, 52 (1).

Bhardwaj, V., Marcos, S., and Manchiraju, S. (2017). The role of impulse buying, hedonism, and consumer knowledge towards sustainable consumption of fast fashion. International Textile and Apparel Association, ITAA Proceedings, 74.

Dholakia, M. U. (1997). An investigation of the relationship between perceived risk and product involvement. Advances in Consumer Research, .24, 159 - 167.

Dhurup, M. (2014). Impulsive fashion apparel consumption: The role of hedonism, fashion involvement and emotional gratification in fashion apparel impulsive buying behavior in a developing country. Mediterranean Journal of Social Sciences, 5(8), 168-177. doi:10.5901/MJSS 2014.v5n8p168

Haq, M.A., Khan, N.R., and Ghouri, A.M. (2014). Measuring the mediating impact of hedonic consumption on fashion involvement and impulse buying behavior. Indian Journal of Commerce and Management Studies, 5 (3), 50-57.

Hirschman, E.C., and Holbrook, M.B. (1982). Hedonic consumption: emerging concepts, methods and propositions. The Journal of Marketing, 46, 92-101. http://dx.doi.org/10.2307/1251707

Kang, J., and Park-Poaps, H. (2010). Hedonic and utilitarian shopping motivations of fashion leadership. Journal of Fashion Marketing and Management, 14 (2), 312-328

Khuong, M.N., and Tran, T.B. (2015). Factors affecting impulse buying toward fashion products in Ho Chi Minh City: A mediation analysis of hedonic purchase. International Journal of Trade, Economics and Finance, 6, (4).

Lam, Y.Y., Lee, S., Ong, J.J., and Tan, W.C. (2017). Young generation's purchase intention towards fashion apparel. Unpublished Research Project. Universiti Tunku Abdul Rahman. Retrieved from; http:// eprints.utar.edu.my/2642/1/MK1701-009.pdf

Osorno, S.C. (2014). Consumer behaviour towards the fashion industry. The fast fashion era.

Kassel:Germany. Retrieved from; https://www.unikassel.de/fb07/ fileadmin/datas/fb07/5Institute/IBWL/ Wagner/EMBS/Correas_Silvia_expose_EMBS.

Rezaei, S., Ali, R.S., Amin, M., and Jayashree, S. (2016). Online impulse buying of tourism products: The role of web site personality, utilitarian and hedonic web browsing. Journal of Hospitality and Tourism Technology, 7(1), 60-83.

Rimpy, G. (2014). A study on purchase intentions of consumers towards selected luxury fashion products with special reference to Pune Region. Mumbai: Dy Patel University. Retrieved from; http:/www. dypatil.edu/schools/management/wp-content/uploads/2015/11/A-Study-on-Purchase-Intentions-ofConsumers-towards-Selected-Luxury-Fashion-Products-with-special-reference-to-Pune-RegionRimpy-Goyal_.pdf

Sherif, M., Sargent, S.(1947). Ego-involvement and the mass media. Journal of Social Issues 3, 8- 16.

Sherif, C.W., Sherif, M., Nebergall, R. (1965). Attitude and attitude change: The social judgment involvement approach. Philadelphia: Saunders.

Sherry, J.F. (1990). A sociocultural analysis of Midwestern flea market. Journal of Consumer Research, 17, 
Issue 1 May/June 2020

13-30.

Zhang, B., and Kim, J. (2013). Luxury fashion consumption in China: Factors affecting attitude and purchase intent. Journal of Retailing and Consumer Services, 20, 68-79. 